\title{
Betonda Bazalt Agreganın Kullanımı ve Özellikleri
}

\author{
Ayhan Orhan ${ }^{1}$, Namık Ak ${ }^{2}$, Ahmet Erensoy $^{3}$, Nurettin Çek ${ }^{4 *}$ \\ ${ }^{1}$ Fırat Üniversitesi, Teknoloji Fakültesi, Metalurji ve Malzeme Mühendisliği, Elazı̆̆, Türkiye (ORCID: 0000-0002-7648-2566) \\ ${ }^{2}$ İstanbul Üniversitesi-Cerrahpaşa Teknik Bilimler MYO Elektrik ve Enerji Bölümü, İstanbul, Türkiye (ORCID: 0000-0001-9119-1567) \\ ${ }^{3}$ Fırat Üniversitesi, Tıp Fakültesi, Parazitoloji Bölümü, Elazı̆̆, Türkiye (ORCID: 0000-0001-6300-1105) \\ ${ }^{4}$ Frrat Üniversitesi, Mühendislik Fakültesi, Metalurji ve Malzeme Mühendisliği Bölümü mezunu, Elazığ, Türkiye (ORCID: 0000-0001-6120-9228)
}

(İlk Geliş Tarihi 10 Mayıs 2020 ve Kabul Tarihi 17 Haziran 2020)

(DOI: 10.31590/ejosat.735019)

\begin{abstract}
ATIF/REFERENCE: Orhan, A., Ak, N., Erensoy, A., \& Çek, N. (2020). Betonda Bazalt Agreganın Kullanımı ve Özellikleri. Avrupa Bilim ve Teknoloji Dergisi, (19), 524-532.

$\ddot{\mathbf{O} z}$

Beton, tüm dünyada kullanılan en yaygın yapı malzemelerinden biridir. Nüfus artışı ve kentleşme nedeniyle önümüzdeki yıllarda beton üretiminin daha da artması beklenmektedir. Sürdürülebilir inşaat kaideleri, daha iyi yalıtım için daha iyi bir termal kütleye sahip olmak için bir inşaat malzemesi gerektirir. $\mathrm{Bu}$, ısıtma ve soğutma amaçlı enerji talebini azaltabilir ve operasyonel kullanım sırasında karbondioksit $\left(\mathrm{CO}_{2}\right)$ emisyonlarını azaltabilir. Bir inşaat malzemesi olarak beton, daha iyi akustik performans sağlayarak ve bina sakinlerinin yaşam kalitesini arttırarak inşaatın sağlık ve refah bilgilerini de arttırabilir. Betonun sürdürülebilir olması için dayanıklı olması da gerekir. Bu, betonun ömrünü uzatacak ve aynı malzemelerin daha uzun süre hizmet verebilmesini sağlayacaktır. Bu aynı zamanda daha az bakım gerektirir. Geri dönüştürülebilen, betonun ısı iletkenlik katsayısını düşüren ve yanmaz doğal agregalar kullanarak 1sı yalıtımı sağlayan beton teknolojisi çevre dostu sistemlerdir. Ekonomik ve teknik değerlendirme ile geri dönüştürülmüş beton üretim teknolojisi üzerine yapılan çalışmalar, çevre koruma ve insanların sürdürülebilir kalkınması üzerindeki bileşimi ve etkisi nedeniyle her ülkede daha fazla ilgi görmüştür. Beton endüstrisi, büyük bir doğal kaynak tüketicisi olarak kabul edilmektedir. Betonun en büyük bileşeni olan doğal agreganın tüketimi, beton üretiminin ve kullanımının artmasıyla sürekli ve hızlı bir şekilde artmaktadır. Bu çalışmada, Elazı̆̆ ilinin Maden ilçesinden elde edilen doğal bazalt kaya agrega olarak seçilmiş ve beton üretiminde kullanılmıştır. Üretilen beton numunelerinin; 1sıl iletkenlik analizleri, dayanım analizleri ve mikroorganizmalara karşı tutumu incelenmiştir. Deney sonuçlarına göre 1sıl iletkenlik katsayıları 0.2401 ila $0.2529 \mathrm{~W} / \mathrm{mK}$ arasında ölçülmüş ve ortalama $0.2497 \mathrm{~W} / \mathrm{mK}$ olarak hesaplanmıştır. İlaveten, beton mukavemetinin $15.33 \mathrm{MPa}$ olarak ölçüldüğü ve normal mukavemetli beton olduğu anlaşılmıştır. Bu çalışmada doğal bazalt agrega ve betonun anaerobik bir ortamda faaliyet gösteren Clostridium bakterilerine karşı dirençli olduğu ve bu bakterilerin hareketinde kısıtlayıcı bir özelliğe sahip olduğu bulunmuştur. Sonuç olarak, dayanıklı, yanıcı olmayan, çevre dostu, toksik olmayan beton yapılmış ve daha sağlıklı ve konforlu bir yaşam ortamı yaratılmasına büyük katkı sağlanmıştır.
\end{abstract}

Anahtar Kelimeler: Kayaç, Beton, Isıl iletkenlik, Dayanıklılık.

\section{Usage and Properties of Basalt Aggregate in Concrete}

\begin{abstract}
Concrete is one of the most prevalent construction material used all over the world. Concrete production in expected to increase upwards in the future years because of the population growth and urbanization. Sustainable construction bases require a construction material to have a better thermal mass for better insulation. This could decrease energy demand for heating and cooling purposes and decrease the carbondioxide $\left(\mathrm{CO}_{2}\right)$ emissions during the operational use. Concrete as a construction material could also improve health and well-being credentials of construction by providing better acoustic performance and improve the life quality of the occupants. Concrete also needs to be durable to become sustainable. This will increase the lifespan of concrete and lead to longer serviceability of the same materials. This also require less maintenance. Concrete technology, which can be recycled, reduces the thermal
\end{abstract}

\footnotetext{
${ }^{*}$ Sorumlu Yazar: Fırat Üniversitesi, Mühendislik Fakültesi, Metalurji ve Malzeme Mühendisliği Bölümü mezunu, Elazı̆̆, Türkiye, ORCID: 00000001-6120-9228, nurettincek001@gmail.com
} 
conductivity coefficient of concrete and provides thermal insulation by using non-combustible natural aggregates, are environmentally friendly systems. The studies on produce technology of recycled concrete with economical and technical valuation has benefited more important interest in each country due to its combination and effect on the environment protection and the sustainable development of people. The concrete industry is accepted as a major consumer of natural resources. Consumption of natural aggregate, which is the biggest component of concrete, increases continuously and rapidly with increasing production and use of concrete. In this study, natural basalt rock obtained from Maden district of Elazig province was chosen as aggregate and used in concrete production. The thermal conductivity analysis, strength analysis and the attitude of the produced concrete samples to microorganisms were examined. According to the experimental results, the thermal conductivity coefficients were measured between 0.2401 to $0.2529 \mathrm{~W} / \mathrm{mK}$ and the average was calculated as $0.2497 \mathrm{~W} / \mathrm{mK}$. In addition, it was understood that concrete strength was measured as $15.33 \mathrm{MPA}$ and it was normal strength concrete. It has been found that in this study, natural basalt aggregate and concrete are resistant to Clostridium bacteria operating in an anaerobic environment and have a restrictive feature in the movement of those bacteria. As a result, durable, non-flammable, environmentally friendly, non-toxic concrete was made and great contribution was made to creating a healthier and more comfortable living environment.

Keywords: Rock, Concrete, Thermal conductivity, Durability.

\section{Giriş}

Geleneksel bina sistemlerinde düşük enerji tasarrufu ve binalardaki inşaat sürecinin istenilen niteliğe (kaliteye) ulaşmaması ve bir kompozit malzeme olan beton yapıda ortaya çıkan sorunlar nedeniyle insanlar endişelenmektedirler. Bu nedenle, insanlar binalarda; yenilikçi sanatsal yapı, hafif, sismik eğilimli alanlara mükemmel yapısal uyumluluk gösteren, etkin 1sıl ve ses yalıtımı gösteren daha sağlam beton arzulamaktadırlar (Bhatti, (2016); Özcan ve Güngör, (2019)). Beton dayanımını arttırmak amacıyla yapılan bir çalışmada beton atığı (concrete waste-CW) geri dönüşüm işleminden geçirilerek ezilmiş beton (crushed concrete-CC) ve kaba kısımdan meydana gelen geri dönüştürülmüş beton agrega (recycled concrete aggregate-RCA) elde edilmektedir. Geri dönüştürülmüş beton agrega çoğunlukla yol yapımı dolgu malzemesi olarak kullanılmaktadır. Betonda doğal iri agrega (Natural aggregate-NA) yerine RCA kullanılması NA talebini azalttığı ve NA'nın korunmasına katkıda bulunduğu için her geçen gün önemini arttırmaktadır. Ancak, bahse konu uygulamalar yalıtım özelliğini artırmada (1sıl iletkenlik katsayısını azaltmada) yani enerji verimliliğini üst düzeye çıkarma konusunda yetersiz kalmıştır. Ayrıca, ilgili çalışmalar genel olarak değerlendirildiğinde, RCA üretimi için NA’ya kıyasla \% 28 daha yüksek doğrudan enerjiye sebep olduğu görülmüştür (Wijayasundara et al. (2017)).

Ticari binalardaki (veya sitelerdeki) enerji tüketiminin \% 29’unu 1sıtma-soğutma ve bunlarla ilişsili enerji tüketimidir. Bu nedenle, yalıtım malzemeleri kullanılarak bu faktörlerden kaynaklanan enerji tüketimi ve çevreye olan olumsuz etkiler azaltılmaya çalışılmaktadır (Biswas et al. (2016)). Bunun için yalıtım malzemeleri ve binalarda kullanılan betonun yalıtım özelliğini arttırmaya yönelik çok sayıda çalışma yapılmaktadır. Binaların enerji verimliliğini arttırmak için yapılan bina dış yalıtımının pahalı olması ve kurulumun uzun zaman alması, araştırmacıları yüksek 1sı yalıtımlı beton geliştirilmesi konusunda çalışma yapmaya yöneltmiştir. Yapılan çalışmalara göre, betonların ısıl iletkenliği, beton bileşenlerinin hafif kaba agregalar veya cam kabarcıkları gibi ısı yalıtım malzemeleri ile değiştirilmesiyle azaltılabilir (Yun et al. (2014)). Betonun yalıtım özelliğini arttırmaya yönelik yapılan çalışmalar, betonun ana unsuru olarak bilinen agregaya dikkat çekerek agrega sayesinde yenilikçi ve sürekli gelişen teknolojiyi temsil eden beton üretimi sağlandığını rapor etmişlerdir (Liu et al. (2016); Marie, (2017)). Betonun ısıl iletkenliğinin; beton yoğunluğu, agregaların türü ve yoğunluğu ile ilişkili olup malzemenin agrega hacim yüzdesi (fraksiyonu) ve nem koşuluna bağlı olduğu anlaşılmıştır (Marie, (2017)). Örneğin; betonda doğal agrega olarak kullanılan kayaçların ısıl iletkenlik katsayılarının 1 ile $9 \mathrm{~W} / \mathrm{mK}$ arasında olduğu rapor edilmiştir (Xing et al. (2015)). Doğal agrega kaynaklarının tükenme problemi, iklim değişikliği problemi, vb. nedenler göz önünde bulundurularak geri dönüştürülmüş agrega içeren termal izolasyon betonu (RATIC) malzeme teknolojisi ortaya çıkarılmıştır. Bu malzeme teknolojisi ile kaba agregaların geri dönüşümü ve önemli bir yüzdesi ile yalıtım agregalarının tasarlanarak çevre üzerinde daha olumlu etki bırakmak ve binalarda enerji verimliliğini artırmak hedeflenmektedir (Liu et al. (2016)).

Tüm bunlarla birlikte doğadaki kaya vb. birçok malzemenin agrega olarak kullanıldığında beton yalıtımı üzerine etkisi konusunda kat edilmesi gereken daha çok yol olduğu aşikardır. İlaveten, en uygun beton malzemesi; düşük ısıl iletkenlik, iyi mekanik dayanım ve mikroorganizmalara karşı dirençli olma özelliklerine sahiptir (Marie, (2017); Cwalina, (2008)). Yapılan çalışmaların büyük çoğunluğunda beton malzemesinin hem ısıl özellikleri hem dayanım özellikleri hem de mikroorganizmalara karşı direnç özellikleri bir arada incelenmemiştir.

Bu çalışmada, biraz daha yol kat edilerek Türkiye'nin Elazı ̆ ilinin Maden ilçesinde bulunan bazalt türü olduğu belirlenen doğal kayaçlar agrega malzemesi olarak kullanılmış, çimento ve su ilave edilerek beton numuneleri yapılmıştır. Numunelerin 1 sıl iletkenlik, dayanım özellikleri ve mikroorganizmalara karşı tutumları incelenmiştir. Bu araştırma, mühendislik uygulamaları için önem arz ederek beton yapımında kullanılan agreganın öneminin anlaşılması ve doğal kayaçların öenminin anlaşılması konularında gerekli bir bilgi ve belge sağlayacaktır.

\section{Materyal ve Metot}

Deneylerdeki beton numunelerinin imalatı için 32.5 R tipi Portland çimentosu (Çimentaş, Elazı̆̆) ve doğal bazalt kayacı agregası kullanılmıştır. Doğal kayaç saf su ile yıkanıp temizlendikten sonra agrega olarak kullanılmış, taramalı elektron mikroskopu (SEM), enerji saçılımlı X-1şınları spektrometresi (EDS) kullanılarak mikro yapı ve elementel özellikleri tespit edilmiştir. Bu çalışmada, ince 
ve kaba olmak üzere iki tip agrega kullanılmıştır. Bunların mineral yapıları aynıdır sadece tane büyüklüğü farklıdır (Yun et al. (2014)). İnce agrega 1-4 mm boyutları arasında, kaba agrega boyutları ise 4-10 mm aralığındadır. Her iki agrega tipi düzgün geometrik şekillerdedir. $1 \mathrm{~cm}^{3}$ şeklinde karot alınan kayaç agregaların ağırlıkları hassas tartı (Kern, Almanya) ile ölçüldü ve yoğunlukları $2.75 \pm 0.05 \mathrm{~g} / \mathrm{cm}^{3}$ olarak hesaplandı. Bu çalışmadaki bazalt yoğunluk değeri, daha önceki çalışmalardaki yoğunluk değerine (2.90 $\mathrm{g} / \mathrm{cm}^{3}$ ) yakındır (Fredlund et al. (2012)). Bu çalışmada kullanılan agrega Şekil 1'de gösterilmiştir.

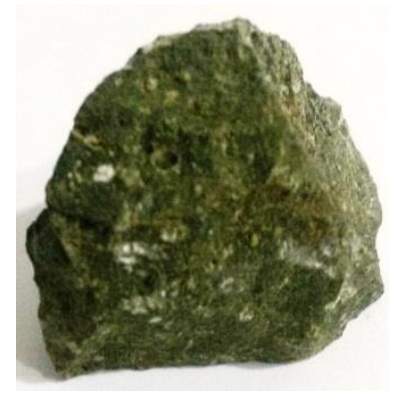

Şekil 1. Agrega olarak kullanılan bazalt kayaç

Beton yapmak için kullanılacak çimento ve agrega karışımının ideal oranlarını tespit etmek için farklı ağırlıkta çimento ve agrega karıştırılmıştır. Karışımın kütlesinin ağırlıkça \% 20’si kadar su ilave edilerek harç yapılmıştır. Beton vb. malzemelerin 1sıl iletkenlik ölçümleri yapan Hotdisk TPS 2500 cihazı $30 \mathrm{cmx} 30 \mathrm{~cm} x 2 \mathrm{~cm}$ boyutundaki beton malzemelerin 1sıl iletkenliklerini ölçebildiğinden yapılan harç $30 \mathrm{cmx} 30 \mathrm{~cm}$ boyutunda, $2 \mathrm{~cm}$ kalınlığındaki kalıba dökülmüştür. Aynı yöntem 4 defa tekrarlanarak özdeş ve türdeş toplam 2 adet kalın agregalı, 2 adet ince agregalı beton numuneleri imal edilmiştir. Numuneler, sıcaklık değeri $15^{\circ} \mathrm{C}$ ile $25^{\circ} \mathrm{C}$ arasında değişen bir ortamda 28 gün boyunca bekletilmiş ve sonra Hotdisk TPS 2500 cihazı kullanılarak 1sıl iletkenlik katsayıları ölçülmüştür. Malzemelerden birim zamanda iletimle geçen 1sı, denklem (1) kullanılarak hesaplandı.

$$
\mathrm{q}=-\mathrm{k} \frac{\mathrm{dT}}{\mathrm{dx}} \quad \text { (Callister and Rethwisch, (2014)) }
$$

Burada, q birim zamanda iletimle geçen 1S1 $\left(\mathrm{W} / \mathrm{m}^{2}\right)$, k 1sıl iletkenlik katsayısı $(\mathrm{W} / \mathrm{mK})$, dT sıcaklık farkı (K) ve dx tabaka kalınlığıdır $\left(\mathrm{m}^{2}\right)$. Bu çalışmadaki beton numunelere, beton basınç test makinesi (Akkaya, Türkiye) kullanılarak basınç uygulandı ve kırılma yükü ölçüldü. Ölçüm sonuçları ve denklem (2) kullanılarak basınç dayanımı hesaplandı.

$$
\text { Dayanım }=\frac{\text { Kırılma yükü }(\mathrm{N})}{\text { Numune yüzey alanı }\left(\mathrm{m}^{2}\right)} \quad \text { (Callister and Rethwisch (2014); Day et al. (2013)) }
$$

Beton yapıların dayanımını ve ömrünü azaltan mikroorganizmalardan birisi de anaerobik ve hızlı büyüyen bir patojen olan Clostridium bakterileridir (Cwalina, (2008); Kiu and Hall (2018)). Bu çalışmada, sulak bir alandaki sediment ortamından alınan çamur, 1şık mikroskopu (SOIF BK5000-TR/L) ile incelendi. Mikroskop görüntülerine göre, sediment çamurunda çoğunlukla Clostridium bakterilerinin mevcut olduğu anlaşıldı. Bu bakterilerin yaşam alanı olan sediment çamuru, temiz su içerisinde yer alan ince ve kalın agrega ortamına ve bu agrega ile yapılan betona $10 \mathrm{~mL}$ olarak yereştirildi. 20 saat kapalı kapta kaldıktan sonra ortamdaki sediment çamuru, agregalar ve beton mikroskop ile incelendi. Böylece bu agregalarla yapılan beton ile Clostridium bakterileri arasındaki etkileşim hakkında fikirler ortaya çıkarıldı.

\section{Bulgular ve Tartışma}

\subsection{Agreganın SEM, elementel ve isıl iletkenlik analizi}

$\mathrm{Bu}$ çalışmada agrega olarak kullanılan doğal kayacın ısıl iletkenlik katsayısı $0.325 \pm 0.05 \mathrm{~W} / \mathrm{mK}$ olarak ölçülmüştür. Kayacın, SEM görüntüsü Şekil 2'de gösterilmiştir. 


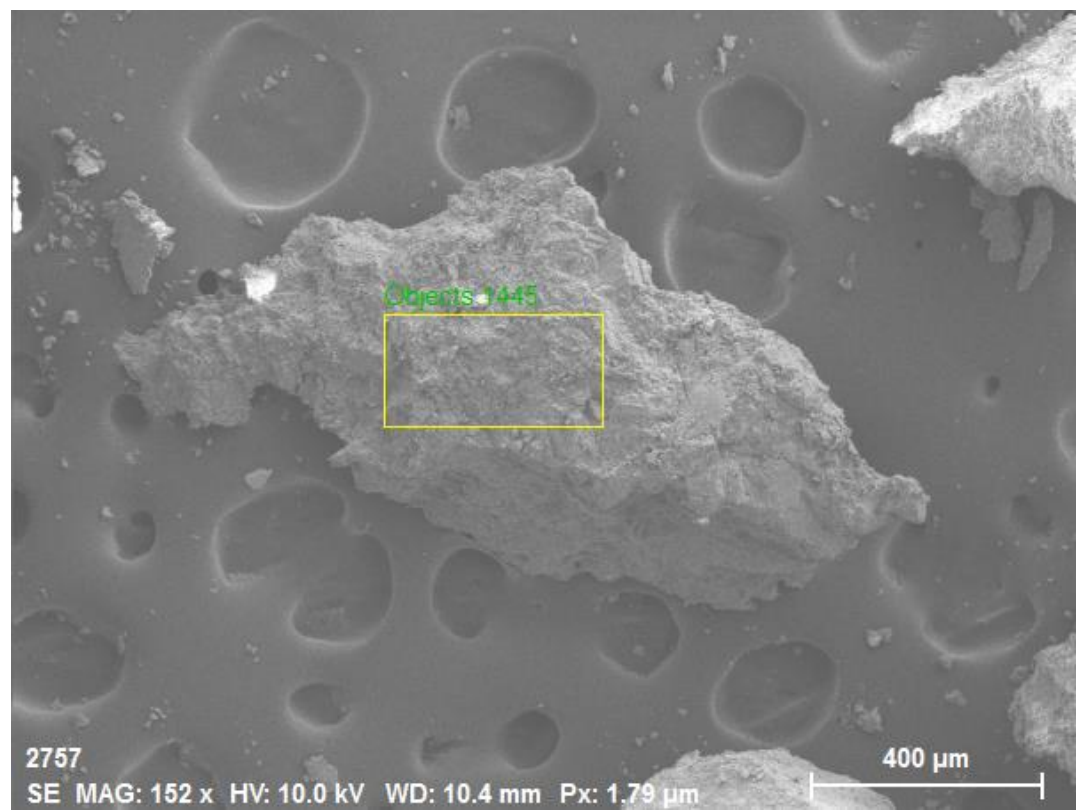

Şekil 2. Doğal kayacın SEM görüntüsü

Şekil 2'de SEM görüntüsü verilen doğal kayacın elementel analiz sonuçları Tablo 1'de verilmiştir.

Tablo 1. Doğal kayacın elementel analizi

\begin{tabular}{lccc}
\hline & $\begin{array}{c}\text { Unn. C } \\
{[\mathrm{wt}]}\end{array}$ & $\begin{array}{c}\text { Norm. C } \\
{[\text { wt.\%] }}\end{array}$ & $\begin{array}{c}\text { Atom. C } \\
{[\text { wt.\%] }}\end{array}$ \\
\hline Oksijen $(\mathrm{O})$ & 28.41 & 44.88 & 58.78 \\
Silisyum (Si) & 15.05 & 23.77 & 17.74 \\
Demir (Fe) & 7.00 & 11.05 & 4.15 \\
Alüminyum(Al) & 4.54 & 7.18 & 5.58 \\
Kalsiyum (Ca) & 2.32 & 3.67 & 1.92 \\
Magnezyum (Mg) & 1.78 & 2.82 & 2.43 \\
Sodyum (Na) & 1.63 & 2.57 & 2.35 \\
Karbon (C) & 2.56 & 4.05 & 7.07 \\
\multicolumn{1}{c}{ Toplam } & 63.29 & 100.00 & 100.00 \\
\hline
\end{tabular}

Tablo 1'deki elementel analiz sonuçları, bazalt ile ilgili yapılan önceki çalışmalar ile uyumludur (Ural, (2012); Ural, (2014); Ural (2019)). Ayrıca bazalt kayaçlarda yüksek oranda oksijen içeriği olduğundan mineralojik yapısı çoğunlukla oksitli bileşik formundadır (Ural, et al. (2015); Kürüm et al. (2018); Ural, (2019); Ural et al. (2019)). Tablo 1'deki analizlerde en çok bulunan element oksijendir. Daha önceki çalışmalara bakıldığında, bu çalışmadaki kayacın bir bazalt olduğu anlaşılmaktadır. Şekil 2'deki SEM görüntüsü dikkatli incelendiğinde kayacın gözenekli ve mikro boşluklara sahip olduğu, boşlukların çapının ise 330 mikrometre ( $\mu \mathrm{m}$ ) boyutlarına kadar ulaştığı görülmektedir. Kumar et al. (2017) tarafından yapılan çalışmada bir malzemedeki mikro boşluklu yapının artması o malzemenin 1sıl iletkenliğini önemli oranda azalttığı rapor edilmiştir. Bu çalışmada agrega olarak kullanılan doğal kayaç mikro boşluklu yapıya sahip olduğu için ısıl yalıtım özelliği göstermekte ve bu bakımından büyük bir avantaja sahiptir. Tablo 2'deki temel analiz sonuçlarında görüldüğü gibi oksijen oranının yüksek olması da 1sıl iletkenlik katsayısının azalması yani 1sıl yalıtımın artması hususunda bir avantajdır. Oksijen (O) atomu; Si, Fe, Al, Ca, Mg ve C atomlarıyla ayrı ayrı kimyasal bağ kurarak kristal yapı sistemlerinde atomların dizilişlerinde kusurları meydana getirerek ısıl ve elektrik iletkenlik değerlerinin azalmasına sebep olmaktadır (Kalpakjian and Schmid, (2010); Callister and Rethwisch, (2014)). Bahse konu sebepler ve sonuçlar Tablo 3'teki veriler ile desteklenmiştir. $\mathrm{Bu}$ çalışmada agrega olarak kullanılan kayaçtaki malzemelerin temel (kristal yapı sisteminde atom dizilişi bozulmamış) ve bileşik (kristal yapıda atom dizilişi bozulmuş) hallerinin ısıl iletkenlik katsayıları Tablo 2'de verilmiştir.

Tablo 2. Doğal kayaçtaki element ve bileşik hallerinin 1sıl iletkenlik katsayıları (Çek, (2016); Fredlund et al. (2012); Kalpakjian and Schmid, (2010); Callister and Rethwisch, (2014))

\begin{tabular}{lclc}
\hline Element & $\begin{array}{c}\text { Isıl iletkenlik katsayısı } \\
(\mathrm{W} / \mathrm{mK})\end{array}$ & Bileşik & $\begin{array}{c}\text { Isıl iletkenlik katsayısı } \\
(\mathrm{W} / \mathrm{mK})\end{array}$ \\
\hline Silisyum $(\mathrm{Si})$ & 148 & $\mathrm{SiO}_{2}$ & $1.3-1.5$ \\
Demir $(\mathrm{Fe})$ & 80 & $\mathrm{Hematit}_{\left(\mathrm{Fe}_{2} \mathrm{O}_{3}\right)}$ & 11.28 \\
Aluminyum $(\mathrm{Al})$ & 205 & $\mathrm{Alümina}\left(\mathrm{Al}_{2} \mathrm{O}_{3}\right)$ & 39 \\
Kalsiyum $(\mathrm{Ca})$ & 201 & $\mathrm{CaO}$ & - \\
Magnezyum $(\mathrm{Mg})$ & 154 & $\mathrm{Magnezya}(\mathrm{MgO})$ & 37.7 \\
Sodyum $(\mathrm{Na})$ & 140 & $\mathrm{Na}_{2} \mathrm{O}$ & - \\
\hline
\end{tabular}

Kayaç agrega içerisindeki elementlerin oksijen ile bileşik kristal yapı sisteminde atomların dizilişinde kusurları meydana getirmesi ve mikro gözenekli yapıya sahip olması nedeniyle kayacın ısıl iletkenlik katsayısı Tablo 3 'teki temel bileşiklerin tümünün 
1sıl iletkenlik katsayılarından daha düşük değerde olmuştur (Kalpakjian and Schmid, (2010); Callister and Rethwisch, (2014)). Literatürde kayaçların ısıl iletkenlik katsayılarının 1 ile $9 \mathrm{~W} / \mathrm{mK}$ arasında olduğu rapor edilmiştir (Xing et al. (2015)). Bu durum göz önünde bulundurulduğunda, bu çalışmada agrega olarak kullanılan kayacın daha düşük 1sıl iletkenlik katsayısına (0.32-0.33 W/mK) sahip olması büyük bir avantajdır. Isıl iletkenlik ölçümleri, SEM, gözenek yapısı, elementel analiz, Tablo 3 'teki veriler ve literatür bilgileri göz önünde bulundurulduğunda bu çalışmada tercih edilen doğal kayaç agreganın betonda 1sıl yalıtımı iyileştirmesi için uygun bir agrega olduğu anlaşılmaktadır.

\section{2. Çimento-agrega ideal oranı ve beton yapı}

Çimento-agrega karışımının ideal oranını tespit etmek için kütlece sabit agrega oranı (1 kg), sabit su oranı yüzdesi (\% 20), kütlece farklı oranlarda çimento $(0.25-2 \mathrm{~kg})$ katılarak yapılan beton numuneleri 10 gün bekletilmiş ve deneylerde elde edilen bulgular Tablo 3 'te verilmiştir.

Tablo 3. Beton-agrega oranlarına bağlı beton durumu

\begin{tabular}{cccl}
\hline $\begin{array}{c}\text { Çimento } \\
\text { oranı }(\mathrm{kg})\end{array}$ & Agrega tipi & $\begin{array}{c}\text { Agrega oranı } \\
(\mathrm{kg})\end{array}$ & Betonun durumu \\
\hline $1 / 4$ & Kaba & 1 & Beton çatlad 1 \\
$1 / 3$ & Kaba & 1 & Beton çatlad 1 \\
$1 / 2$ & Kaba & 1 & Beton çatlamad 1 \\
1 & Kaba & 1 & Beton çatlad 1 \\
$1 / 4$ & İnce & 1 & Beton çatlad 1 \\
$1 / 3$ & İnce & 1 & Beton çatlamad 1 \\
$1 / 2$ & İnce & 1 & Beton çatlad 1 \\
1 & İnce & 1 & Beton çatlad 1 \\
\hline
\end{tabular}

Tablo 3'teki bilgilerden anlaşılacağı üzere kaba agrega kullanılarak çatlamayan beton yapmak için ideal karışım oranları 1 birim çimento içerisine 2 birim kaba agrega yerleştirilecek şekilde olması gerekir. İnce agrega kullanılarak çatlamayan beton yapmak için ideal karışım oranları 1 birim çimento içerisine yaklaşık 3 birim ince agrega yerleştirilecek şekilde olmalıdır.

\subsection{Beton ısıl iletkenlik ölçümü}

Bu çalışmada 1sıl iletkenlik ölçümleri yapan cihaz $30 \mathrm{cmx} 30 \mathrm{~cm} 2 \mathrm{~cm}$ boyutundaki malzemelerin 1sıl iletkenliklerini ölçtüğünden beton numuneler $30 \mathrm{~cm} \times 30 \mathrm{~cm} 2 \mathrm{~cm}$ boyutunda tasarlanmıştır. Bu boyutlardaki beton numunelerinin her biri için $1.5 \mathrm{~kg}$ çimento, 3 kg agrega ve 450 g (karışımın ağırlıkça 20\%'si oranında) su kullanılmıştır. Yapılan beton numuneleri Şekil 3’te gösterilmiştir.

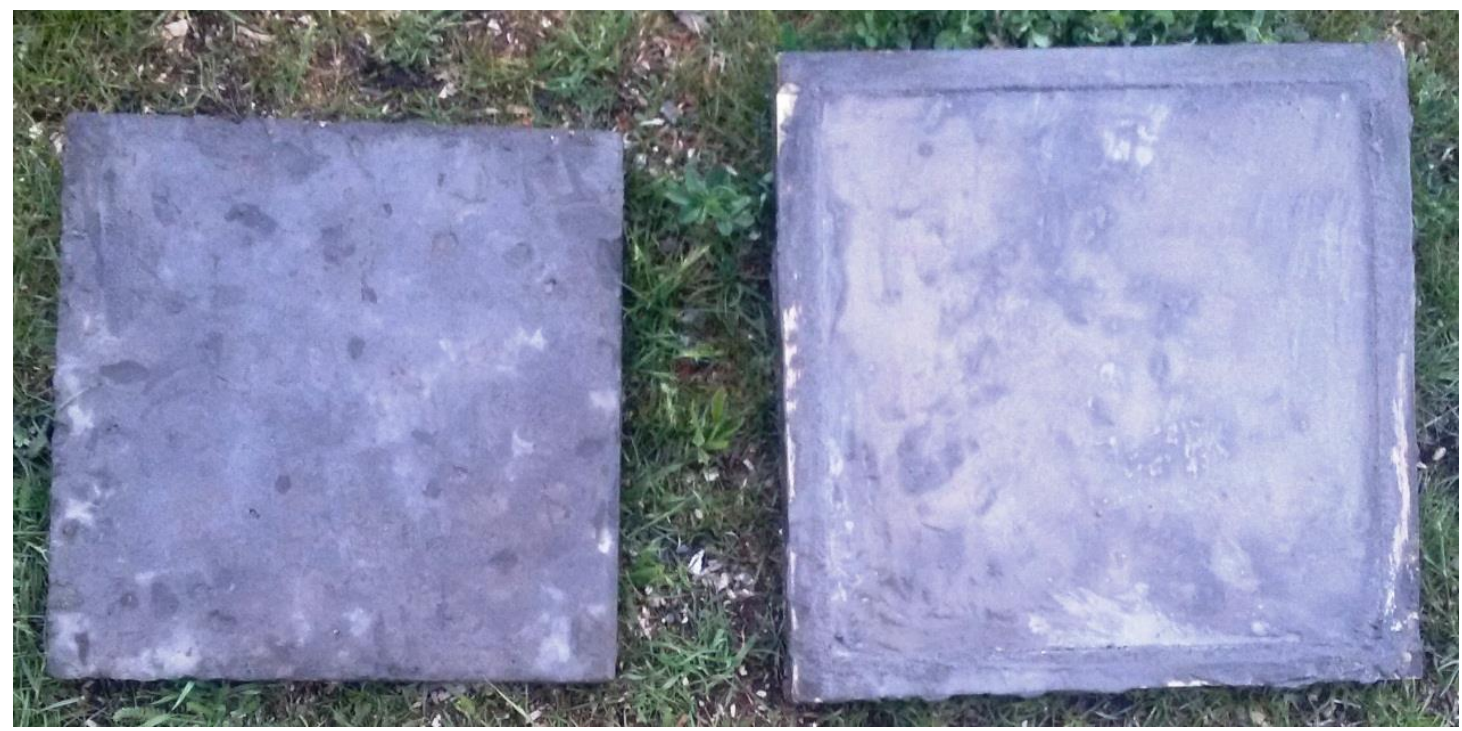

a) Kalıptan çıkarılmış beton

b) Kalıp içerisindeki beton

Şekil 3. Isıl iletkenlik ölçümünde kullanılan beton numuneleri

Beton içerisine katılmayan, binalarda dış cepheleri örterek kaplayan karbon yapılı (poliüretan, polistren, selülöz ve dahası) yalıtım malzemeleri çok düşük ısıl iletkenlik katsayısına sahiptirler. Ancak, onlar çok erken yanabilme, yangınlara karşı dayanıksız olma, toksik duman çıkarma, vb. konularda büyük bir dezavantaja sahiptirler (Schiavoni et al. (2016)). Tüm bu faktörler göz önünde bulundurulduğunda yanmayan ve düşük ısıl iletkenlik katsayısına sahip yalıtım malzemeleri geliştirmek büyük önem arz etmektedir. Ayrıca, binalarda betonu başka bir malzeme ile örterek kaplayıp ısıl iletkenlik katsayısını azaltmak yerine yanmayan, yangına dayanıklı toksik dumanı olmayan, düşük 1sıl iletkenlik katsayısına vb. özelliklere sahip agrega kullanılarak düşük 1sıl iletkenlik katsayısına sahip beton geliştirmek daha doğru bir mühendislik stratejisi olacaktır. Beton yapımında kullanılan çeşitli agregalar ve 1sıl iletkenlik değerleri Tablo 4'te verilmiştir. 
European Journal of Science and Technology

Tablo 4. Farklı agregalar kullanılarak yapılan betonların 1sıl iletkenlik katsayıları

\begin{tabular}{lcl}
\hline Beton Yapılan Malzeme türü & $\begin{array}{c}\text { Isıl iletkenlik } \\
\text { katsayısı (W/mK) }\end{array}$ & Kaynak \\
\hline \% 20 RCA+\% 10 Geri dönüştürülmüş agrega & 0.79 & Marie, (2017) \\
\% 20 Kauçuk agregası & 0.90 & Marie, (2017) \\
Geri dönüşürülmüş beton agregası (RCA) & 0.91 & Marie, (2017) \\
Kauçuk kırıntısı (20 \%) agregası & 1 & Marie, (2017) \\
Yedek agregalı beton & $\sim 1.25$ & Yun et al. (2014) \\
Bor nitrür & 1.82 & Kim et al. (2017) \\
Normal beton & 2.25 & Yun et al. (2014) \\
Bor nitrürün seramikleşme öncesi polisilazan kaplaması & 3.9 & Kim et al. $(2017)$ \\
\hline
\end{tabular}

Bu çalışmada agrega olarak kayaç kullanılarak yapılan beton numunelerinin 28 gün sonunda 1sıl iletkenlik katsayıları ölçülmüş ve elde edilen sonuçlar Tablo 5'te verilmiştir.

Tablo 5. Bu çalıșmadaki beton numunelerinin 1sıl iletkenlik katsayıları

\begin{tabular}{cc}
\hline Numune & Isıl iletkenlik katsayısı (W/mK) \\
\hline Beton numunesi 1 (Kalın agregalı) & 0.2401 \\
Beton numunesi 2 (Kalın agregalı) & 0.2547 \\
Beton numunesi 3 (İnce agregalı) & 0.2514 \\
Beton numunesi 4 (İnce agregalı) & 0.2529 \\
Ortalama & 0.2497 \\
\hline
\end{tabular}

Tablo 5'teki verilerden anlaşılacağı üzere bu çalışmadaki betonların ısıl iletkenlik katsayıları $0.2401 \mathrm{~W} / \mathrm{mK}$ ile $0.2547 \mathrm{~W} / \mathrm{mK}$ aralığında ve 4 adet beton numunesinin 1 sıl iletkenlik katsayılarının aritmetik ortalama $0.2497 \mathrm{~W} / \mathrm{mK}$ olarak tespit edilmiştir. Bu çalışmada kullanılan kayaç agreganın kalın veya ince olmasının betonun ısıl iletkenlik katsayısına önemli bir oranda etkisi olmadığı ortaya çıkmıştır. Ayrıca, Tablo 4 ve Tablo 5 karşılaştırıldığında bu çalışmadaki doğal agrega ile yapılan betonların ısıl iletkenlik katsayılarının daha düşük olduğu apaçık ortadadır. Denklem 1, Tablo 5 'teki verilere uygulandığında bu çalışmada imal edilen beton ile Tablo 5'teki malzemelere kıyasla \% 58.87 ila \% 93.60 oranında birim zamanda geçen 1sı (q) azaltılır. Böylece, Tablo 5'teki malzemelere kıyasla bu çalışmadaki beton ile \% 58.87 ila \% 93.60 oranında enerji tasarrufu yapılabilir.

\subsection{Beton mukavemet analizi}

Beton numuneleri $(15 \mathrm{cmx} 15 \mathrm{cmx} 15 \mathrm{~cm}) 28$ günlük bekletildikten sonra onların basınç dayanım testleri yapılmış olup Şekil 4 ’te gösterilmiştir.

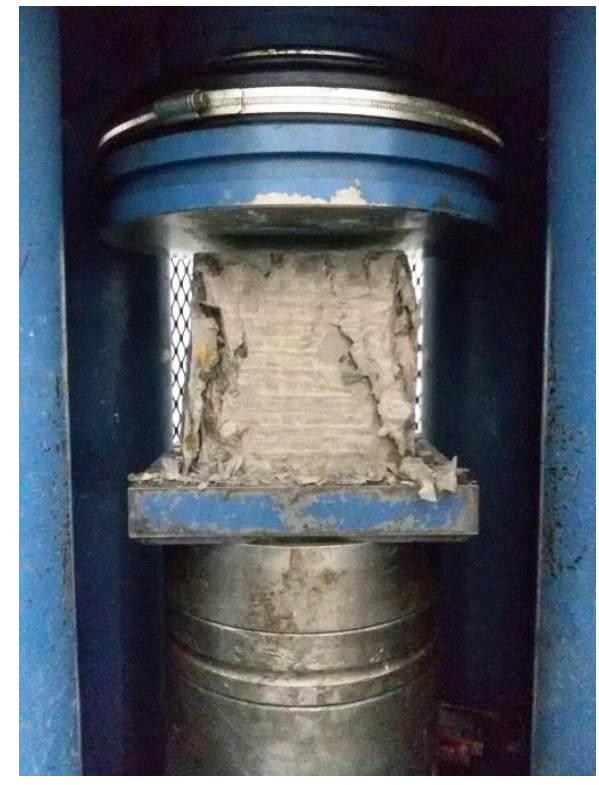

Şekil 4. Beton numunelerinin basınç dayanımı testi

Şekil 4'te görüldüğü gibi basınç dayanım testi yapılan beton numunelerinin kırılma yükleri $345 \pm 1 \mathrm{kN}$ olarak tespit edilmiştir. Ortalama basınç dayanımı denklem 2 ile hesaplanmıştır. Denklem 2, bu çalışmaya uygulanırsa bu çalışmadaki betonların ortalama basınç dayanımları denklem 3 'teki gibi olur.

$$
\frac{\text { Kırılma yükü }(\mathrm{N})}{\text { Numune yüzey alanı }\left(\mathrm{m}^{2}\right)}=\frac{345000}{0.0225}=15333333 \mathrm{~N} / \mathrm{m}^{2}=15.33 \mathrm{MPa}
$$

Önceki çalışmalardaki bazı beton çalışmalarının basınç dayanımları Tablo 6' da verilmiştir. 
Avrupa Bilim ve Teknoloji Dergisi

Tablo 6. Literatürdeki bazı beton çalışmalarının basınç dayanımı

\begin{tabular}{lcc}
\hline \multicolumn{1}{c}{ Beton türü } & Basınç dayanımı (MPa) & Kaynak \\
\hline \% 20 RCA+10\% RA & 19 & Marie, (2017) \\
\% 20 Geri dönüştürülmüş agrega (RA) & 20 & Marie, (2017) \\
\% 20 RCA & 22.3 & Marie, (2017) \\
\hline
\end{tabular}

Tablo 6'de görüldüğü gibi bu çalışmadaki betonun basınç dayanım değeri (ortalama $15.33 \mathrm{MPa}$ ), literatürdekilerine yakındır. Basınç dayanım değerleri $15 \mathrm{MPa}$ değerinin altında olan betonlar düşük dayanımlı beton, 15-30 MPa arasında olan betonlar normal dayanımlı beton olarak kabul edildiğinden, Tablo 6'daki çalışmalarda olduğu gibi bu çalışmada normal dayanımlı beton imal edilmiştir (Day et al. (2014)). Agreganın düzgün geometrik (prisma, kübik, hegzagonal vb.) şekillerde olması dayanıklılığı arttırdığı literatürde rapor edilmiştir (Gao et al. (2017)). Bu çalışmada kullanılan agregalar kübik, hegzagonal, octoganal vb. düzgün geometrik şekillerde olduğundan beton dayanımını sağlamakta önemli bir katkı sağlamaktadır.

\subsection{Agreganın ve betonun bakterilere karşı davranışı}

$\mathrm{Bu}$ çalışmadaki sediment çamurunda büyük çoğulukla Clostridium bakterileri mevcuttur. Bu bakteriler, mikroskopta 40X ve 100X büyütme yapılarak gözlemlenmiştir. Mikroskopun özelliği olarak 40X büyütmede bakterilerin boy, genişlik, çap gibi özellikleri ölçülebilmektedir. Yapılan çalışmalarda belirtildiği edildiği gibi bu çalışmadaki Clostridium bakterileri 1.6-20 $\mu$ m uzunluğunda ve 0.5-2 $\mu \mathrm{m}$ genişliğindedir (Rusnak and Smith, (2014)). Ayrıca, Clostridium bakterileri anaerobik (oksijensiz) ortamlarda yaşamaktadırlar (Edwards et al. (2013)). Bu nedenle 24 saat kapalı kapta bekletilerek anaerobik ortam oluşturulan sediment çamurunun mikroskop görüntüleri Şekil 5 'te verilmiştir.

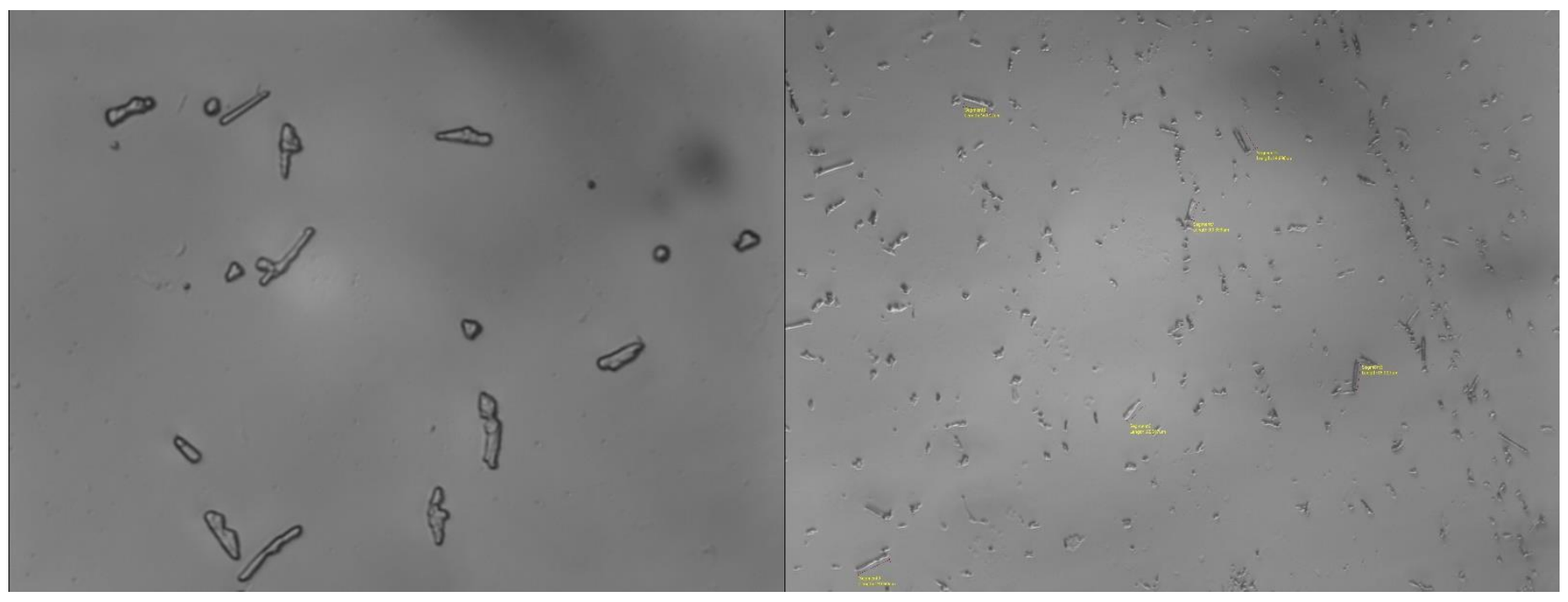

a) $100 \mathrm{X}$

b) $40 \mathrm{X}$

Şekil 5. Sediment çamurundaki Clostridium bakterileri

Şekil 5'teki görüntülerdeki bakteriler hareketlilerdir. Ancak agrega ortamına katılan ve 20 saat kapalı kapta bekletilen Clostridium bakterilerinin hareket etmedikleri yani hareketsiz oldukları görülmüştür. $\mathrm{Bu}$ da, agrega ortamının Clostridium bakterilerinin hareket kabiliyetlerini yitirmelerine sebep olduğunu göstermektedir. Bunun sebebinin, Tablo 1'de verilen agreganın elementel analizinde görüldüğü gibi, özellikle de oksijen oranının fazla olmasının oksijensiz (anaerobik) ortamda yaşayan bakteri olan Clostridium bakterilerinin yaşama ihtimallerini düşürdüğünden ve $\mathrm{Na}, \mathrm{Mg}, \mathrm{Ca}$ gibi elementlerinin oksijen veya diğer malzemelerle tepkimeye girip tuz oluşturarak Clostridium bakterilerinin yaşamalarına engel teşkil ettiğinden kaynaklandığını düşünmekteyiz (Shockey and Borger, (1991)). Bu çalışmada kullanılan bazalt agregası Clostridium bakterilerinin karşı dirençli bir malzemedir ve onların yaşamalarını, gelişmelerini, hareket etmelerine engel teşkil etmekte olduğu için antibakteriyel bir etki göstermiştir. Bu bazalt agregası kullanılarak yapılan beton ortamına konulan Clostridium bakterileri mikroskop ile incelenmiştir. Agregada olduğu gibi betonda da Clostridium bakterilerinin hareket etmedikleri görülmüştür. Yani bazalt agregası ile yapılan beton Clostridium bakterilerinin yaşamlarına ve gelişmelerine karşı direnç göstermiştir. Bu nedenle, bazalt agregası ile yapılan beton antibakeriyel bir özellik göstermiştir.

\section{Sonuçlar}

Bu çalışmada, agrega olarak kullanılan doğal bazalt malzemesinin 1sıl iletkenlik katsayısı $0.325 \pm 0.05 \mathrm{~W} / \mathrm{mK}$ olarak ölçülmüştür. $\mathrm{Bu}$ agrega kullanılarak yapılan betonlar, 1sıl iletkenlik testlerine tabii tutulmuş ve test sonuçlarına göre farklı agrega malzemelerinin kullanılmasıyla hazırlanan betonlara göre daha düşük 1sıl iletkenlik katsayısına sahip olmuş olup 1sıl iletkenlik katsayıları 0.2401 ila $0.2547 \mathrm{~W} / \mathrm{mK}$ aralığındadır. Bazalt agregası ile yapılan betonların özelliklede, geri dönüştürülmüş agregalarla yapılan betonlara kıyasla daha düşük ısıl iletkenlik katsayısına sahip olması bazalt agregasının bir üstünlüğü olup bu agrega sayesinde yapılarda daha yüksek enerji verimliliği sağlanacağı görülmüştür. İlaveten, bazalt malzemesinin yanmaması, toksik duman çıkarmaması ve doğal olması da bir başka üstünlükleridir. Böylece bu çalışmada; yanmayan, çevre dostu, toksik etkisi olmayan beton yapılarak daha sağlıklı 
ve daha konforlu bir yaşam ortamı ortaya çıkarmasına büyük katkı sağlanmıştır. Günümüzde yeşil bina fikrinin önemi anlaşıldığı için ekolojik inşaat malzemelerine olan tercih artmaktadır. Özellikle, endüstrileşmiş ülkelerde toprak yapı malzemeleri tercih edilmekte ve bu tercihin en önemli sebepleri çevre hassasiyeti ve rahat bir iç mekan ambiyansı sağlamak olarak kabul edilmektedir (Emiroğlu et al. (2015)). Kayaçlar da toprak yapı malzemelerinden biri olmakla birlikte bu çalışmada beton agregası olarak kullanılmaları ile betonun 1sıl iletkenlik katsayısı azaltılarak çevre hassasiyeti konusunda çok büyük hassasiyet gösterilmiş, yanmayan, toksik etsisi olmayan, ekolojik inşaat malzemesi tasarlanmış ve yeni bir agrega tipinin keşfi hususunda önemli bir adım atılmıștır. Bunlarla birlikte, bu çalışmada bazalt agregası kullanılarak imal edilen betonların basınç dayanımları 15.33 MPa seviyelerinde olup normal dayanımlı beton sınıfına girerek yapılarda kullanımı uygundur. Yapılacak daha ileri çalışmalar ile bazalt agrega kullanılan betonların basınç dayanımlarının arttırılması ve yüksek dayanımlı beton sınıfına yükselmesi gelecek hedeflerinden biridir. Bazalt agregasının ve bu agraga ile yapılan betonların Clostridium bakterilerine karşı dirençli malzemeler olması büyük bir üstünlük olup özellikle de anaerobik (oksijensiz) ve sediment ortamlarda kullanılabilecek uygun bir beton olarak karşımıza çıkmıştır. Ancak özellikle de mikroorganizmalara karşı dirençlilik yönünün daha detaylı araştııılmasına ihtiyaç vardır.

\section{Kaynakça}

Bhatti, A. Q. (2016). Application of dynamic analysis and modelling of structural concrete insulated panels (SCIP) for energy efficient buildings in seismic prone areas. Energy and Buildings, 128 (2016) 164-177.

Biswas, K., Shrestha, S. S., Bhandari, M. S., Desjarlais, A. O. (2016). Insulation materials for commercial buildings in North America:An assessment of lifetime energy and environmental impacts. Energy and Buildings, 112, 256-269.

Callister, W. D., Rethwisch, D. G. (2014). Materials Science and Engineering an Introduction. $9^{\text {th }}$ Edition. Wiley, United States of America.

Cwalina, B. (2008). Biodeterioration of Concrete. Architecture Civil Engineering Environment, 4, 133-140.

Çek, N. (2016). Parçacıklar ve Enerji Kaynakları. Lambert Academic Publishing, Saarbrucken.

Day, K. W., Aldred, J., Hudson, B. (2013). Concrete Mix Design, Quality Control and Specification. $4^{\text {th }}$ Edition. CRC Press.

Edwards, A. N., Suárez, J. M., McBride, S. M. (2013). Culturing and Maintaining Clostridium difficile in an Anaerobic Environment. Journal of Visualized Experiment, 79, 1-8.

Emiroğlu, M., Yalama, A., Erdoğdu, Y. (2015). Performance of ready-mixed clay plasters produced with different clay/sand ratios. Applied Clay Science, 115, 221-229.

Fredlund, D. G., Rahardjo, H., Fredlund, M. D. (2012). Unsaturated Soil Mechanics in Engineering Practice. John Wiley\&Sons.

Gao, D., Zhang, L., Nokken, M. (2017). Compressive behavior of steel fiber reinforced recycled coarse aggregate concrete designed with equivalent cubic compressive strength. Construction and Building Materials, 141, 235-244.

Kalpakjian, S., Schmid, S. R. (2010). Manufacturing Engineering and Technology. Sixth Edition, Pearson, London.

Kim, K., Ryu, S., Kim, J. (2017). Melt-processable aggregated boron nitride particle via polysilazane coating for thermal conductive composite. Ceramics International, 43, 2441-2447.

Kiu, R., Hall, L. J. (2018). An update on the human and animal enteric pathogen Clostridium perfringens. Emerging Microbes\&Infections, 7 (141), 1-15.

Kumar, S., Gupta, R. C., Shrivastava, S. (2017). Effective utilisation of quartz sandstone mining wastes: A technical note on its thermal resistance. Journal of Cleaner Production, 140, 1129-1135.

Kürüm, S., Bölücü, A., Ural, M. (2018). Geochemistry and Petrogenesis of Intracontinental Basaltic Volcanism on the Northwest Arabian Plate, Gaziantep Basin, Southeast Anatolia, Turkey. ACTA GEOLOGICA SINICA, 92 (2), 519-535.

Liu, Y. Wang, W., Chen, Y. F., Ji, H. (2016). Residual stress-strain relationship for thermal insulation concrete with recycled aggregate after high temperature exposure. Construction and Building Materials, 129, 37-47.

Marie, I. (2017). Thermal conductivity of hybrid recycled aggregate-Rubberized concrete. Construction and Building Materials, 133, 516-524.

Özcan, U., Güngör, S. (2019). Sürdürülebilir Bir Yöntem Betonda Puzolan Kullanımı. Avrupa Bilim ve Teknoloji Dergisi, 15, 176182.

Rusnak, J. M., Smith, L. A. (2014). Botulinum Neurotoxins from Clostridium botulinum. In book: Manual of Security Sensitive Microbes and Toxins, CRC Press, New York, 451-466.

Schiavoni, S., D'Alessandro, F., Bianchi, F., Asdrubali, F. (2016). Insulation materials for the building sector: A review and comparative analysis. Renewable and Sustainable Energy Reviews, 62, 988-1011.

Shockey, W. L., Borger, D. C. (1991). Effect of Salt on Fermentation of Alfalfa. 2. Treatment with Sodium Chloride, Clostridium butyricum, and Lactic Acid Bacteria. Journal of Dairy Science, 74 (1), 160-166.

Ural, M. (2012). Elazı̆̆ ve Malatya çevresindeki Yüksekova karmaşı̆̆ bazik volkanitlerinin petrokimyası, petrolojisi ve yaşı. Doktora Tezi, Fırat Üniversitesi Fen Bilimleri Enstitüsü, Elazığ.

Ural, M. (2014). Morphologic and physical features of pillow basalts of the Yüksekova Complex around Elazığ (Eastern Anatolia, Turkey). Journal of Tethys, 2(1), 70-80.

Ural, M. (2019). Geochemistry of the Volcanic Rocks of the Yüksekova Complex near Güneyköy (SE of Elazı̆̆g, E Turkey). Avrupa Bilim ve Teknoloji Dergisi, 17, 1125-1133.

Ural, M., Arslan, M., Göncüoglu, M. C., Tekin, U. K., Kürüm, S. (2015). Late Cretaceous arc and back-arc formation within the southern Neotethys: Whole-rock, trace element and $\mathrm{Sr}-\mathrm{Nd}-\mathrm{Pb}$ isotopic data from basaltic rocks of the Yüksekova Complex (Malatya- Elazı̆g, SE Turkey). Ofioliti, 40 (1), 57-72. 
Ural, M., Deniz, K., Sayit, K. (2019). Mafic Volcanic and Subvolcanic Rocks from the Yüksekova Complex in the İçme-Kesikköprü Province (East of Elaziğ, Eastern Turkey): Whole-Rock Geochemistry and Confocal Raman Spectroscopy Characterization. In: IOP Conference Series: Earth and Environmental Science, 362(1), p.012122.

Yun, T. S., Jeong, Y. J., Youm, K-S. (2014). Effect of Surrogate Aggregates on the Thermal Conductivity of Concrete at Ambient and Elevated Temperatures. The Scientific World Journal, 2014, 1-9.

Wijayasundara, M., Crawford, M. R., Mendis, P. (2017). Comparative assessment of embodied energy of recycled aggregate concrete. Journal of Cleaner Production, 152, 406-419.

Xing, Z., Beaucour, A-L., Hebert, R., Noumowe, A., Ledesert, A. (2015). Aggregate's influence on thermophysical concrete properties at elevated temperature. Construction and Building Materials, 95, 18-28. 